\title{
Unsung Heroes: Constituency Election Agents in British General Elections
}

\section{Justin Fisher (Brunel University), David Denver (Lancaster University) \& Gordon Hands} (Lancaster University)

\author{
Contact: \\ Dr. Justin Fisher \\ Deaprtment of Politics \\ Brunel University \\ Uxbridge \\ Middlesex \\ UB8 3PH \\ Email: justin.fisher@brunel.ac.uk
}

Tables: $\quad 9$ 


\title{
Unsung Heroes: Constituency Election Agents in British General Elections
}

\begin{abstract}
Despite their central role in the electoral process, constituency agents have been largely overlooked by political scientists and this article seeks to rectify the omission. It sketches the origins and development of the role of agent from the late nineteenth century and suggests that a serious re-think of the role took place in the 1990s. Survey-based evidence about the social characteristics of agents is presented confirming that they are largely middle-aged, middle-class, welleducated men. They are also becoming more experienced, offer realistic assessments of the impact of constituency campaigning and, arguably, many take a long-term view of how their party's support can be maximised.
\end{abstract}

\section{Introduction}

At British general elections, every candidate in every constituency is required to appoint an election agent and, as Blackburn (1995: 270) suggests, these agents are the second most important figures in constituency-level electioneering, after the candidates. In the first place, they are legally responsible for the conduct and financial management of campaigns. Under the terms of the Representation of People Act 1983, the agent must use 'all reasonable means to prevent corrupt or illegal practices at the election'. In addition, legitimate campaign spending can only be incurred and paid by (or with the express authorisation of) the election agent. No one else is allowed to spend money in promoting a candidate's election. In the event of any breach of election rules, the agent is personally liable and a result could be declared void. Since 2001, agents have also had the significant additional responsibility of 
ensuring compliance with the Political Parties, Elections and Referendums Act which, among other things, requires them to provide the Electoral Commission with details of donations made to their campaign.

In addition to these legal requirements, however, most agents also take on the task of organising and leading the election campaign in the constituency. The agent sets up the campaign headquarters, recruits the campaign team, organises the preparation of the election address and other literature and generally ensures that all necessary preparations are made. He or she usually then runs the campaign itself and is the main contact with parties' national and regional headquarters. Among a multitude of tasks, and as well as dealing with finance, the agent will co-ordinate canvassing and the distribution of leaflets, organise the candidate's activities, liaise with headquarters on visits by key party figures, and organise and co-ordinate the efforts of volunteer campaign workers throughout the campaign and, in particular, on polling day itself. ${ }^{1}$

Clearly, then, agents are at the very heart of the parties' campaigning machinery in the constituencies. Moreover, it is now widely accepted that the quality of the constituency campaigns mounted under the leadership of election agents can make a significant difference to how well their party performs (see, for example Denver et al., 2004; Pattie and Johnston, 2003; Whiteley and Seyd, 2003). It seems not unreasonable, therefore, to think of agents as 'heroes' of the electoral process in Britain, especially given that the great majority of them take on their legal responsibilities and undertake the arduous task of running campaigns on an entirely voluntary basis. 
Yet agents are largely overlooked in academic studies of elections and to that extent they are 'unsung' heroes. In Kavanagh's (1970) work on constituency electioneering, for example, election agents merit only one page reference in the index and only a few mentions in the entire text. The Nuffield study of the 2001 election makes only one substantive comment on the role of agents (Butler and Kavanagh, 2002: 212) and, as far as we are aware, there is no recent published research on the characteristics and attitudes of agents. ${ }^{2}$

In this article we seek to rectify this omission by exploring the changing roles of agents. As we shall see, constituency campaigning and the importance attached to it by the parties changed significantly in the 1990s. In these new circumstances, the parties began to reconsider the role of agents and to find new ways of organising constituency campaigns. We also use data derived from three surveys of agents carried out immediately following the general elections of 1992, 1997 and 2001 to provide some evidence about the changing demographic characteristics and experience of agents as well as their opinions on the utility of campaigning and about the purposes of the campaigns that they organise. First, however, we briefly sketch the origins and evolution of the post of constituency election agent.

\section{The constituency election agent: origins and development of the role}

The position of constituency election agent as we now know it can be traced back to the Corrupt and Illegal Practices Act of 1883. Before then, candidates had regularly employed agents both to maximise the numbers of their supporters who were registered to vote and to manage campaigns. Most of these were solicitors, often belonging to firms specialising in political business, some being local and others coming from large firms in London. Some served regularly in the same constituency - Hanham (1978: 236) even suggests that in many 
counties the position became hereditary - but it was not a full-time occupation. The role of the agent at this point is succinctly summarised by Hanham (236):

The election agent was essentially a man who organised a team of up to several thousand paid workers, so that they got through the essential work of canvassing and making arrangements for taking electors to the polling booths with the minimum of friction, with the maximum of noise and publicity, and with as few breaches of the law as seemed to him desirable.

Dickens' account of the fictional Eatanswill election in The Pickwick Papers (ch.13) is a colourful illustration of how elections were run at this time. There was extensive intimidation, bribery and corruption, and the 1883 Act was only one of a series of measures by which Parliament attempted to stamp this out. The Act introduced strict limits on election expenditure in constituencies and, in order to enforce these limits, laid down rules for making payments and for declaring election expenses. The responsibility for complying with these rules was laid on a single individual - the election agent.

Hanham argues that 'a new class of full-time agents had come into existence by 1885 ' (240), although this was the culmination of developments that had been going on for some time. In particular, of course, the extension of the franchise and the growth of constituency electorates had been making the whole business of organising elections more complex. Solicitor-agents, associated with the old corrupt system, gave way to what was essentially a new profession, particularly at first in the Conservative party in the north of England. These new agents were appointed on a permanent basis to maintain the party's organisation in the constituency, to run the party office, to liaise with the candidate and local worthies, to help with local election 
campaigns, and to prepare for and manage the general election campaign. A North of England Conservative Agent's Association was founded as early as 1872, almost 20 years before the setting up of the National Society of Conservative Agents in 1891. Things changed more slowly in the Liberal party, but followed the same pattern. The 1883 Act in effect gave a legal foundation to these developments. Swaddle (1990) couples it with the Reform Act of 1884, which further extended the franchise, and the Redistribution Act of 1885, which made single-member constituencies the norm, and argues that 'the profession of full-time party agents, in the modern sense, was largely a product of the reforms of 1883-85' (p. 73).

Since the late nineteenth century election agents have remained key figures in constituency campaigns. What has changed, however, has been the importance attributed to constituency campaigns by commentators and the parties themselves. Until about the first decade of the twentieth century there effectively was no national campaign - a general election consisted simply of the individual campaigns mounted by candidates in the various constituencies that were contested. Over most of the following century, however, the national campaign gradually grew in importance and there was a corresponding down-grading of the significance of constituency campaigns. There were two main reasons for this. On the one hand, the further growth of constituency electorates and the maintenance of the tight and effective spending limits inaugurated by the 1883 Act meant that it was difficult for local organisations to mount effective campaigns that would reach all of the voters. More important in the long run, however, was a series of developments in techniques of mass communication which made it much more cost-effective for the parties to mount national campaigns (for which there were no expenditure limits) - first came mass circulation newspapers, then radio and finally, and most decisively, television. Already by the 1950s, 
there had been a marked decline in the status and significance of constituency campaigns, prompting the Nuffield study of the 1959 election to comment that they were 'relics of a bygone age' (Butler and Rose, 1960: 119). The widespread ownership of television and the development of television as the principal means of political communication by the political parties only served to confirm this view. The election agent might have remained a key figure in constituency campaigns but commentators were sceptical, to say the least, about whether constituency campaigns mattered.

Nonetheless, the numbers of full-time agents remained very large throughout the first half of the twentieth century. The Nuffield study of the 1950 election (Nicholas, 1951: 24-41) reported that the Conservatives had well over 500 full-time agents - the backbone of what at that time was widely regarded as the most effective party election machine. But even Labour - whose organisation was notoriously ramshackle - had 279, while the Liberals (who were about to be almost extinguished as a political force) had 350 paid agents during the election. ${ }^{3}$ This may well have been the high point for full-time agents, however. Since then, their numbers have declined fairly steeply in all three parties, although the Conservatives have always had most. Precise and authoritative figures are hard to come by but the Nuffield studies suggest that Conservative numbers were down to 'about 300 ' by 1987 , whereas Labour had 70 full-time agents in 1979 and only 43 in 1983.

What these trends reflect is essentially a de-professionalisation of the role of agent, and the reasons are not hard to understand. Only the largest and most affluent of constituency party organisations could afford the salary of a full-time official; although a few might move on to positions in their party's regional or national organisation, the great majority of full-time agents had no prospect of promotion to increase responsibility or salary; and the declining 
status of constituency campaigning (and perhaps of politics too) would make the job less attractive. The trend, then, was very much towards volunteer agents, appointed by candidates simply to run a campaign. These volunteers might typically be local councillors or constituency party officials - people with plenty of knowledge of the local political scene and perhaps years of experience of working in election campaigns. There would also be many cases, as there had been even in the heyday of the professional agent, where the party was very weak and a candidate was standing merely to show the flag, in which it would be a matter of finding someone - frequently a member of the candidate's family or a friend - who could be cajoled into doing the job.

\section{Changes in the 1990s}

But the story does not end there. During the 1990s the parties (and academics) began to reassess the importance of constituency campaigning. A dealigned electorate was more receptive to persuasion and mobilisation by the parties, and technological developments especially computers - significantly improved the tools available for fighting local campaigns. As a result, central party staff began to take constituency campaigning much more seriously.

Party managers realised that there was an important job to be done in the constituencies but they also increasingly came (or were forced) to the view that employing full-time agents locally or relying entirely on voluntary agents is not the best way to do it - even although the law still requires the appointment of a local agent. The main problems have already been referred to - parties lacked the resources to employ very many permanent full-time agents and the job itself was not very attractive to well-qualified professionals. One response by the parties was that national party professionals sought to exercise much greater control over 
local campaigning by managing key constituency campaigns in crucial respects and integrating them much more closely into the national effort. What emerged over the decade was, in effect, a new relationship between the national and local campaigns (Denver et al., 2003) A second response, as we shall see, has been to try to ensure that volunteers have the training necessary to develop the organisational skills and abilities that can profitably be brought to bear at constituency level.

In addition, however, all three parties have looked for other ways to ensure that professional expertise is available to key constituency campaigns. Since 1997 the Conservatives have begun to employ and part-finance local agents from the centre. They still had around 300 traditional locally-employed agents in 1992, but by 1997 that number had fallen to around 200, with now an additional 100 employed from Conservative Central Office. By 2001 there had been a further marked decline: there were now only 60 traditional full-timers, with about 40 centrally-appointed agents. But the party has also begun to make more radical changes. Following the 1997 election, it abolished its regional tier of organisation and moved to a system in which Area Campaign Directors had responsibility for a number of seats, usually covering one or two counties.

Labour's response has been rather different. The funding available to MPs to hire staff has increased quite rapidly over the past few years, and in a number of cases researchers or personal assistants appointed by MPs (or in some cases MEPs) have then served as agents at the next election. More generally, however, the party has begun to appoint special organisers - people specially recruited, trained and appointed on short-term contracts - to particular target constituencies (or groups of constituencies) in the run-up to elections, to oversee preparations and then to organise the campaign itself. Quantifying the numbers here is a little 
difficult: in some cases special organisers would actually take on the role of agent, but in others they would concentrate on giving guidance to voluntary agents in a number of seats. On the basis of information drawn from several sources, we estimate that in 1992 Labour had around 70 traditional full-time agents (an increase of about 30 on 1983), with 20 special organisers servicing a range of constituencies; in 1997, the number of full-time agents was around 40, but nearly all of the 90 key seats identified by the party had a special organiser (or so it was claimed); in 2001 there had been a further fall in the number full-time agents, to around 30, but again every 'priority' seat had the services of a special organiser, although, since there were 148 of these seats, there had to be some 'doubling up'.

The Liberal Democrats do not have the resources to undertake programmes on this scale but, even so, in 2001 party headquarters provided financial assistance to allow paid agents or parttime organisers to be employed in key seats. About 100 constituencies had some form of paid assistance, although in many cases this involved sharing an organiser with other seats. In addition two Assistant Campaign Directors were appointed at national level to assist and encourage the development of effective constituency campaign organisations.

In an earlier piece of work Denver and Hands (2002) suggested that developments in constituency campaigning in the 1990s could be seen as an example of 'Post-Fordism'. Changes in campaign strategies and methods were comparable to changes in production processes - from mass production using relatively unskilled labour (Fordism) to the production of specialist products and niche marketing, involving hi-tech equipment and a highly-trained, versatile work force (Post-Fordism). Although the analogy is somewhat speculative, it sheds some light on changes in the role of election agents and in the organisation of constituency campaigns. One of the watchwords of Post-Fordism is 'flexible 
specialisation' and campaigns have become more flexible. The parties have moved away from a traditional model in which the agent co-ordinates the carrying out of fairly simple and repetitive tasks (house-to-house canvassing, leafleting, getting out the vote on polling day) to a strategy which uses advanced technology and a greater range of expertise to focus differentiated campaigning on different groups within the electorate (target voters in target seats). As this happens, it could be argued that the traditional agent and the traditional constituency campaign are gradually being superseded.

Here, however, we now go on to discuss agents and their role in recent elections on the basis of data collected in 1992, 1997 and 2001. First, we consider the social characteristics of agents. Basically we are seeking to answer the question 'who are agents?' and to consider, in particular, whether they are drawn from the same demographic groups that are regularly found to have relatively high levels of political participation. Secondly we consider the extent of agent 'professionalisation' in an era in which there are fewer full-time members of this 'profession'. Finally, we consider whether agents take a strategic and rational approach to their role, given that inevitably some will be working in constituencies where their candidates are effectively assured of either victory, or of defeat.

\section{Who are the agents?}

As noted previously, very little is known about the characteristics of election agents. In this section, therefore, we provide some evidence describing the sex, age, education and occupation of the different types of agents in the major parties. The data are derived from a series of surveys of election agents carried out immediately following the general elections of 1992, 1997 and 2001. ${ }^{4}$ The principal aim of the surveys was to gather information about the nature and intensity of campaigning in the constituencies, but at the same time they also 
provide information about the kind of people who were agents, their experience and training and their views on the efficacy of campaigning. We show first, in Table 1 , the numbers of respondents of each type from each of the parties. ${ }^{5}$

\section{[Table 1 About Here]}

Two points need to be made about these figures in the light of the general trends discussed above. First, the numbers of Conservative permanent agents seem rather large by comparison with those suggested in our earlier discussion, certainly in 1992 and 2001. There are two reasons for this. Full-time agents were probably more likely to respond to the surveys than voluntary agents and, in addition, our figures include those permanently employed by local parties on a part-time basis whereas figures reported in the Nuffield studies and elsewhere are likely to take 'full-time' more literally.

Second, the figures for Labour may appear to under-represent special organisers. It should be remembered, however, that special organisers frequently acted as advisors rather than being agents themselves. In 1997 and 2001 we asked a separate question about whether campaigns were allocated a special organiser and 43 and 56 voluntary Labour agents respectively reported that their campaigns were assisted by a special organiser.

In general, however, there are clear differences between the parties. Although the numbers of permanent Conservative agents clearly declined over the period, there were many more than in the other parties. Permanent Labour agents also declined in number but, unsurprisingly, the Liberal Democrats always had fewest. In all parties, however, 'other paid agents' begin to appear from 1997. Even so, volunteers always form the vast majority of agents for Labour and Liberal Democrat candidates. It is worth noting, however, that permanent and paid agents 
are concentrated in seats that are held by the party concerned and 'target' or 'key' seats which are likely to see a close result. In 2001, for example, $87 \%$ of the Conservatives' paid agents, 94\% of Labour's and $65 \%$ of the Liberal Democrats' were in held or target seats.

We turn next to the socio-demographic characteristics of agents. Although the numbers involved are not large, acting as an agent is an intense form of political participation (Fisher and Webb, 2003) and we would expect that the demographic profile of agents would be similar to that of others having high levels of political activity. In other words, as Fisher and Webb (2003) found in their study of Labour Party employees, we would expect agents to be drawn from socio-demographic groups with higher levels of resources - for example: time, experience - and also higher levels of political efficacy. Table 2 provides information about the sex and age of agents in the three elections considered here.

[Table 2 About Here]

Overall, men greatly outnumber women among election agents. Upwards of three-quarters of Labour and Liberal Democrat agents have been men at each of the three elections for which figures are available. The Conservatives, on the other hand, have been significantly more receptive than the other parties to female agents ${ }^{6}$ (despite the difficulties that Central Office has experienced in trying to get local associations to adopt women candidates in winnable seats). This may reflect the fact that women form a relatively large proportion of Conservative party members - around 49\% according to survey data from the early 1990s (Whiteley, Seyd \& Richardson 1994: 43) as compared with 39\% of Labour members (Seyd \& Whiteley, 2002: 35) and 47\% of Liberal Democrats, also in the early 1990s (Bennie et al., 1996: 137). Although the trends are not statistically significant, there are signs in the data 
that women are becoming more involved as permanent agents. In all three parties, the proportion of males among this category has declined over the period.

Considering the data on age, it is perhaps not surprising that, on average, the oldest group in every case is voluntary agents. ${ }^{7}$ In many constituencies the job is taken on by retired people - indeed, in all three elections many retired full-time agents continued to act in a voluntary capacity for the Conservatives. Permanent agents are clearly younger, on average, and there is some evidence that both the Conservatives and Labour have used nationally appointed agents and special organisers to bring in a somewhat younger group of experts. There is little difference between the parties in terms of agents' ages but Labour and the Liberal Democrats might have some cause for concern in that the average age of their agents increased significantly between 1992 and 2001.

[Table 3 About Here]

Table 3 shows the proportions of agents with degrees. As a group, election agents are much more highly educated than the general population (among whom 19.7 percent had a degree or degree-equivalent qualification at the time of the 2001 census) and than members of their respective parties. In the early 1990s only 12 per cent of Conservative members had university degrees (Whiteley, Seyd \& Richardson, 1994: 44) while towards the end of the decade 34 per cent of Labour members were graduates (Seyd \& Whiteley, 2002: 34). . Liberal Democrat agents are, by some way, the most likely to have had higher education and the differences between the parties are statistically significant for each election. In all three parties, however, the proportions with degrees are almost always largest among other paid agents, suggesting that the recruitment of relatively young graduates to organise and manage 
constituency campaigns was a common response to the need for effective campaigning in the 1990s.

[Table 4 About Here]

Finally in this section, Table 4 shows the occupational status of voluntary agents. The pattern is much as would be expected. For all three parties, the majority - usually a substantial majority - of voluntary agents have professional and administrative or white collar backgrounds. These sorts of people are most likely to bring to the job the kinds of organisational skills and experience required. Only small proportions of agents are manual workers. This is so even in the Labour party, where the proportion of manual workers has fallen significantly over the period - a trend which mirrors the decline of manual workers among Labour party members in general (Seyd \& Whiteley, 2002: 35).

Summarising drastically, we can say that the typical voluntary agent is likely to be a man, over 50, on balance likely to have a degree and to have a professional, administrative or white-collar occupation. Permanent agents are likely to be around 10 years younger, but less likely to have a degree. Special organisers are likely to be younger still, but more likely than either voluntary or full-time agents to have a degree. More generally our speculation that agents would mirror other high-participation groups is confirmed - men, the middle-aged, those with high levels of education and those from business and professional occupations are over-represented among agents. Indeed, in the case of the latter, this is becoming even more pronounced. These findings are in line with Fisher and Webb (2003), who found that Labour employees in general were most likely to be middle class and have a degree. Agents, then, like employees (or at least, Labour employees), follow the same patterns in terms of predictors of activity as other more conventional forms of political participation. 


\section{Experience and Training}

We have suggested that the occupational background of voluntary agents is likely to be a significant source of expertise but two other important sources, for both voluntary and fulltime agents, are experience and training.

Clearly agents who have had previous experience of organising election campaigns will have a better idea of what is involved, and be more skilled in all aspects of campaigning. Table 5 provides information about the previous campaigning experience of agents and, overall, the figures suggest that the agents of the major parties have become increasingly experienced. Only the data for Conservative voluntary agents show no significant increase over the three elections although their agents have usually been somewhat more experienced than those of either of the other two parties. As we have seen, the number of full-time Conservative agents has declined quite sharply over the period and if, as seems likely, the more senior and more experienced agents were the ones retiring, this would tend to counteract any trend towards greater experience. One further point, not shown in the table, is worth making. Both the Conservatives and Labour made significant numbers of appointments in the category we have labelled 'other paid agents' for the 1997 election. In most cases the Conservative appointees were centrally-appointed agents, whereas the Labour ones were special organisers drafted into key constituencies. But both groups were relatively inexperienced - only 36 per cent of Conservative and 39 per cent of Labour other paid agents had previously organised a campaign. By 2001, however, these figures had risen to 63 per cent for Conservatives and 70 per cent for Labour. Presumably many of the people appointed in 1997 were either still in post or had been reappointed, so that the numbers with no experience fell substantially.

[Table 6 About Here] 


\section{Unsung Heroes}

Apart from appointing as agents people who bring expertise from their occupational backgrounds or who have previous experience of organising elections, the other main way in which the national parties can improve the expertise of their agents is by providing training in campaign organisation and techniques. This has always been done, of course, but as the focus on constituency campaigning has increased over the past fifteen years or so, the parties have put renewed efforts into training. Since it was clear from the early 1990s, as the ownership and use of personal computers became widespread, that this new technology would have significant applications in campaigning, we asked in all three surveys not just about training in general campaigning techniques but also more specifically about training in the use of computers for campaigning.

Table 6 shows the proportions of the different types of agents saying that they attended partyorganised courses giving general training in campaigning over the previous 5 years as well as the proportions of all agents who received training in the use of computers. In terms of general training, the proportions reporting that they received some training are consistently very large. The figures are almost always well over 60 per cent, and for permanent and other paid agents generally around 90 per cent. Of course, the figures tell us nothing about the nature or extent of the training, but it is clear that all three parties were putting considerable effort into improving the expertise of their agents, with the Conservatives generally training more of their agents than the other parties. The figures for all agents show a significant downward trend from 1992 in all parties and it seems likely that this is because, as we have seen, agents were in general becoming more experienced so that in many cases training would not need to be repeated. 
The figures for training in the use of computers also show a significant and quite sharp decline from 1992 onwards. There are probably a number of factors at work here. By the middle 1990s the ownership of personal computers was becoming widespread and their use in offices almost universal. The need for training, certainly among voluntary agents would therefore be likely to reduce. But in any case, agents might well delegate the campaign's computer tasks to another member of the campaign team who was particularly adept or experienced in the use of computers. Certainly other evidence does not suggest that local campaigns were suffering from a lack of computer expertise: the proportions of all campaigns making use of computers rose from 74 per cent in 1992, to 85 per cent in 1997 and 89 per cent in 2001 (Denver et al, 2003: 550).

The evidence presented in this section suggests that although Labour and the Liberal Democrats rely heavily on voluntary agents, and the Conservatives increasingly do so, all three parties have taken steps to build up the expertise of agents as a whole. They have been increasingly successful in retaining the services of agents with previous experience and they have organised training for impressive proportions of agents, whether voluntary, permanent or special organisers. Arguably, this is consistent with the 'post-Fordism' thesis advanced by Denver and Hands (2002). Rather than relying on relatively unskilled labour to perform the role of agents, all parties have tried to ensure that their body of agents, whether paid or unpaid, have become highly trained and skilled in the use of the high technology equipment necessary for modern election campaigns.

\section{The effectiveness and purposes of constituency campaigning}

The surveys of agents from which the data discussed in the preceding sections are derived were used to construct a measure of campaign intensity for each party in each constituency on the basis of information about campaign activities supplied by respondents (see Denver 
and Hands, 1997: 246-55). In addition, however, we also asked agents to evaluate the impact of their own campaigns on the election outcome in their constituency (although these evaluations did not form part of the measure of campaign intensity). Table 7 shows the proportions of agents claiming that their campaigns made 'a great deal' of difference to the number of votes that their party obtained according to the target status of their constituency. ${ }^{8}$

One might expect to find some exaggeration here - most people will experience some psychological resistance to admitting that activities into which they have put considerable effort have little impact - but the pattern of responses makes reasonably good sense. Agents in seats that were not held and not targeted (mostly hopeless prospects for the party concerned) were least likely to think that their efforts made a great deal of difference. ${ }^{9}$ Labour and the Liberal Democrat respondents in target seats are most likely to believe that campaigning had a payoff while among Conservatives it is agents in the safest seats who are most likely to have a positive view of the electoral effects of campaigning. This may appear odd, but we have shown elsewhere that the Conservatives mounted their best campaigns in these seats, at least in 1992 and 1997 (Denver et al, 2003). In addition, the very low figures for the Conservatives in all types of seats in 1997 suggests that, in the face of the Labour landslide in that election, Conservative agents believed that it was impossible to stem the tide no matter how well they campaigned. Finally, Liberal Democrat agents in hopeless seats (not held and not targeted) were clearly realistic about the impact that their (usually weak) campaigns had on the constituency result. All of this suggests that as 'electoral professionals' agents have a relatively sophisticated view of the effectiveness of their own efforts. This potentially distinguishes them from more regular partisans.

[Table 7 About Here] 
We also asked agents about the aims and purposes of their campaigns. A straightforward electoral maximizing view of campaigning would suggest that the purpose is simply to win votes and seats. On this view, it is rational to concentrate resources on target constituencies and run minimal campaigns elsewhere and the parties have increasingly followed this logic. What may appear rational to political scientists or to central party professionals may not be so rational from an agent's perspective, however. After all, a traditional academic view of constituency campaigning was that it was largely a ritual that kept party members happy (Kavanagh, 1970: 78-9). Even if this view was ever correct, it is now almost entirely wrong, at least in the eyes of agents. We asked agents whether, apart from gaining as many votes as possible, their campaigns had any other major aims, and if so what they were: barely eight per cent of agents mentioned boosting party morale in 1992 and by 2001 this figure had fallen to less than one per cent.

Nonetheless, the figures reported in Table 8 suggest that relatively few agents take a wholly electoral-maximizing view of campaigns. Although there is a decline in the proportions of Labour and Liberal Democrat agents mentioning other aims over the period, large majorities of agents in all parties claim that their campaigns have purposes other than maximising votes. Although their campaigns tend to have the least impact on party performance (Denver et al., 2004), Conservative agents are the least likely to say that they have additional aims and the differences between the parties are statistically significant at each election.

\section{[Table 8 About Here]}

If campaigns are not just about winning votes, what other purposes do they serve? A number of common themes emerge from responses to an open-ended question - to publicise the party, promote policies, contact the electorate, boost party morale, keep the opposition busy, raise 
funds, improve organisation, come second, increase membership and prepare for the local elections. However, only the latter two aims are mentioned in any numbers, or with any regularity. Details are given in Table 9. Agents in all parties clearly view election campaigns as an opportunity to recruit party members. Canvassing helps to identify supporters and in the excitement of an election campaign it is easier than usual to persuade at least some of these to sign up as members. The data also suggest that agents increasingly view general election campaigns as an opportunity to campaign also for forthcoming (or contemporaneous) local elections. ${ }^{10}$ The traditional view has been the reverse - that local election campaigns assist in the build up to a general election. What the data suggest, however, is that agents may be becoming more sophisticated electoral maximizers. The purpose is to win votes, whether at local or constituency level; and there may be an increasing appreciation that the election of local councillors (as well as recruiting new members) may provide a springboard for subsequent success at general elections. It is noteworthy that Liberal Democrats are most likely to offer this response given that a feature of Liberal Democrat success at parliamentary level has been preceding success in relevant local elections (MacAllister et al, 2002).

\section{[Table 9 About Here]}

\section{Conclusion}

The discussion presented here has suggested a number of important developments in the organisation of constituency election campaigns. To start with, we have confirmed the already well-documented decline of the traditional full-time agent. He (mostly) or she was someone employed on a permanent basis by a local party to maintain the party's organisation between elections and then take charge of organising the campaign when the general election was called. In their heyday election agents could lay claim to professional status - they were trained in particular skills to carry out a distinct set of tasks. But at least since 1950 numbers 
of full-time agents have declined steadily and this no longer seems a viable model for bringing expertise to constituency campaigns.

As we have argued here and elsewhere, however, the traditional mould of constituency campaigning has been broken over the past ten years or so - at least in the all-important target constituencies. The parties have woken up to the potential of constituency campaigning and in different ways have been looking for new organisational models to realise that potential. A campaign organisation centred on the traditional agent no longer suffices - and such agents probably only survive because of the continuing legal requirements that each candidate must appoint one. We have suggested that the notion of flexible specialisation associated with the post-Fordist model of the process of production may shed some light on these changes. Whether it does or not, we can expect further significant changes over future elections. Ironically, perhaps, the 'heroic' role of election agents is only being celebrated as it becomes obsolete. 
Table 1: Numbers of agents responding to surveys (row \%)

\begin{tabular}{cccc}
\hline $\begin{array}{c}\text { Permanent } \\
\text { agents }\end{array}$ & $\begin{array}{c}\text { Other } \\
\text { paid agents }\end{array}$ & $\begin{array}{c}\text { Voluntary } \\
\text { agents }\end{array}$ & Total \\
\hline
\end{tabular}

Conservative

$\begin{array}{lllrlrll}1992 & 181 & (69 \%) & * & & 81 & (31 \%) & 262 \\ 1997 & 163 & (38 \%) & 83 & (19 \%) & 180 & (42 \%) & 426 \\ 2001 & 136 & (37 \%) & 43 & (12 \%) & 189 & (51 \%) & 368\end{array}$

Labour

$\begin{array}{llllllll}1992 & 44 & (12 \%) & * & & 310 & (88 \%) & 354 \\ 1997 & 32 & (7 \%) & 31 & (7 \%) & 382 & (86 \%) & 445 \\ 2001 & 24 & (5 \%) & 23 & (5 \%) & 392 & (89 \%) & 439\end{array}$

Liberal Democrat

$\begin{array}{llllllll}1992 & 22 & (6 \%) & * & & 338 & (94 \%) & 360 \\ 1997 & 16 & (4 \%) & 7 & (2 \%) & 382 & (94 \%) & 405 \\ 2001 & 17 & (4 \%) & 9 & (2 \%) & 399 & (94 \%) & 425\end{array}$

Note: * The relevant question was not asked in 1992. 'Permanent agents' means full-time or parttime agents employed by the local party. 'Other paid agents' refers to agents or special organisers employed by the national party to work in the constituency, or other organisers seconded by MPs, MEPs or trade unions. 
Table 2: Sex and age of agents

\begin{tabular}{cccc}
\hline $\begin{array}{c}\text { Permanent } \\
\text { agents }\end{array}$ & $\begin{array}{c}\text { Other } \\
\text { paid agents }\end{array}$ & $\begin{array}{c}\text { Voluntary } \\
\text { agents }\end{array}$ & All \\
\hline
\end{tabular}

Sex (\% male)

Conservative

$\begin{array}{llrll}1992 & 65 & * & 65 & 65 \\ 1997 & 63 & 68 & 70 & 67 \\ 2001 & 61 & 58 & 73 & 67\end{array}$

Labour

$\begin{array}{llrll}1992 & 86 & * & 79 & 80 \\ 1997 & 81 & 65 & 75 & 75 \\ 2001 & 67 & 78 & 76 & 76\end{array}$

Lib Dem

$\begin{array}{lllll}1992 & 76 & * & 78 & 78 \\ 1997 & 60 & 43 & 76 & 75 \\ 2001 & 53 & 78 & 79 & 78\end{array}$

Mean Age

Conservative

$\begin{array}{llcll}1992 & 44.4 & * & 56.9 & 48.3 \\ 1997 & 45.3 & 41.3 & 54.8 & 48.5 \\ 2001 & 48.2 & 41.0 & 54.9 & 50.8\end{array}$

Labour

1992

1997

2001

Lib Dem

1992

1997

2001
37.0

36.5

41.2
41.0

42.2

46.0

40.0

41.2

$*$

44.4

44.1
46.6

50.1

51.2

45.9

48.6

50.4

Note: Ns as in Table 1.

67

80

75

6


Table 3: Education of agents (\% with degree)

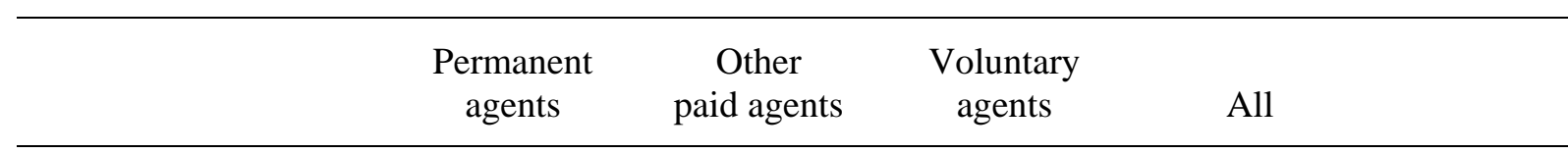

Conservative

$\begin{array}{llrll}1992 & 41 & * & 48 & 43 \\ 1997 & 35 & 48 & 46 & 42 \\ 2001 & 42 & 59 & 47 & 47\end{array}$

Labour

$\begin{array}{llrll}1992 & 48 & * & 52 & 51 \\ 1997 & 50 & 77 & 52 & 54 \\ 2001 & 54 & 70 & 58 & 59\end{array}$

Lib Dem

$\begin{array}{llrll}1992 & 67 & * & 62 & 64 \\ 1997 & 67 & 86 & 64 & 65 \\ 2001 & 82 & 78 & 65 & 66\end{array}$

Note: Ns as in Table 1.

Table 4: Occupational status of voluntary agents (row \%)

\begin{tabular}{ccc}
\hline Business & Professional & Manual \\
$\&$ management & \& administrative & workers \\
\hline
\end{tabular}

Conservative

$\begin{array}{llll}1992 & 25 & 63 & 5 \\ 1997 & 24 & 63 & 4 \\ 2001 & 35 & 51 & 8\end{array}$

Labour

1992

13

65

$70-10$

2001

17

62

10

Lib Dem

$\begin{array}{rrrr}1992 & 27 & 61 & 7 \\ 1997 & 26 & 60 & 10 \\ 2001 & 23 & 69 & 5\end{array}$

Note: Ns as in Table 1. 
Table 5: Previous experience of agents (\% having previously organised at least one general election campaign)

\begin{tabular}{ccccccc}
\hline & \multicolumn{2}{c}{ Conservative } & \multicolumn{2}{c}{ Labour } & \multicolumn{2}{c}{ Liberal Democrats } \\
& $\begin{array}{c}\text { All } \\
\text { agents }\end{array}$ & $\begin{array}{c}\text { Voluntary } \\
\text { agents }\end{array}$ & $\begin{array}{c}\text { All } \\
\text { agents }\end{array}$ & $\begin{array}{c}\text { Voluntary } \\
\text { agents }\end{array}$ & $\begin{array}{c}\text { All } \\
\text { agents }\end{array}$ & $\begin{array}{c}\text { Voluntary } \\
\text { agents }\end{array}$ \\
\hline 1992 & 58 & 54 & 38 & 35 & 35 & 35 \\
1997 & 51 & 44 & 38 & 37 & 43 & 43 \\
2001 & 63 & 47 & 50 & 48 & 47 & 49 \\
\hline
\end{tabular}

Note: Ns as in Table 1.

Table 6: General training (and computer training) of agents (\% attending courses)

\begin{tabular}{cccc}
$\begin{array}{c}\text { Permanent } \\
\text { agents }\end{array}$ & $\begin{array}{c}\text { Other } \\
\text { paid agents }\end{array}$ & $\begin{array}{c}\text { Voluntary } \\
\text { agents }\end{array}$ & $\begin{array}{c}\text { All } \\
\text { agents }\end{array}$ \\
\hline
\end{tabular}

Conservative

$\begin{array}{llllll}1992 & 91 & - & 78 & 87 & (51) \\ 1997 & 82 & 92 & 70 & 78 & (39) \\ 2001 & 79 & 93 & 57 & 69 & (24)\end{array}$

Labour

$\begin{array}{llllll}1992 & 96 & - & 77 & 79 & (36) \\ 1997 & 88 & 90 & 69 & 72 & (21) \\ 2001 & 88 & 87 & 66 & 68 & (20)\end{array}$

Lib Dem

$\begin{array}{rrrrrr}1992 & 91 & - & 71 & 72 & (21) \\ 1997 & 100 & 71 & 60 & 62 & (12) \\ 2001 & 94 & 89 & 62 & 64 & (13)\end{array}$

Note: Ns as in Table 1. The figures in brackets are the percentages of all agents who attended computer training courses. 
Table 7: Perceptions of effectiveness of campaigns (\% thinking their campaign made 'a great deal' of difference)

$\begin{array}{ccc}\text { Held/ } & \text { Target } & \text { Not held/ } \\ \text { not target } & \text { not target }\end{array}$

Conservative

$\begin{array}{llll}1992 & 43 & 30 & 30 \\ 1997 & 25 & 19 & 18 \\ 2001 & 44 & 33 & 13\end{array}$

Labour

$\begin{array}{llll}1992 & 38 & 49 & 37 \\ 1997 & 34 & 53 & 46 \\ 2001 & 28 & 47 & 25\end{array}$

Lib Dem

$\begin{array}{rrrr}1992 & - & 52 & 8 \\ 1997 & - & 78 & 12 \\ 2001 & 60 & 59 & 9\end{array}$

Note: The numbers of respondents in held/not target, target and not held/not target seats were as follows: Conservative 135, 45, 82 (1992); 164, 63, 199 (1997); 122, 101, 145 (2001): Labour 97, 95, 162 (1992); 168, 63, 214 (1997); 183, 96, 160 (2001); Liberal Democrat 0, 31, 329 (1992); 1, 28, 376 (1997); 10, 32, 383 (2001). 
Unsung Heroes

Table 8: Campaigns having aims other than maximising votes (\%)

\begin{tabular}{rcccc}
\hline & $\begin{array}{c}\text { Held/ } \\
\text { not target }\end{array}$ & Target & $\begin{array}{c}\text { Not held/ } \\
\text { not target }\end{array}$ & All \\
\hline Conservative & & & & \\
1992 & 58 & 53 & 78 & 63 \\
1997 & 63 & 51 & 61 & 60 \\
2001 & 61 & 53 & 63 & 60 \\
Labour & & & & \\
1992 & 70 & 59 & 93 & 78 \\
1997 & 76 & 71 & 81 & 78 \\
2001 & 66 & 57 & 80 & 69 \\
Lib Dem & & & & \\
1992 & & & & \\
1997 & - & 74 & 94 & 78 \\
2001 & - & 68 & 88 & \\
\hline
\end{tabular}

Note: For Ns see note 5. 
Table 9: Most frequently mentioned 'other' aims of campaigns (\%)

\begin{tabular}{|c|c|}
\hline $\begin{array}{c}\text { Increase } \\
\text { membership }\end{array}$ & $\begin{array}{l}\text { Prepare for } \\
\text { local elections }\end{array}$ \\
\hline
\end{tabular}

Conservative

$\begin{array}{lll}1992 & 31 & 12 \\ 1997 & 44 & 17 \\ 2001 & 39 & 27\end{array}$

$\begin{array}{lll}2001 & 39 & 27\end{array}$

Labour

$\begin{array}{lll}1992 & 30 & 32 \\ 1997 & 23 & 23 \\ 2001 & 26 & 38\end{array}$

Liberal Democrat

1992

62

33

1997

42

41

2001

36

51

Note: Percentages are of respondents reporting that they had another aim in addition to maximising votes. Ns for the respective elections are 148, 249 and 209 for Conservatives, 260, 333 and 291 for Labour and 327, 342 and 325 for Liberal Democrats. 


\section{Unsung Heroes}

\section{Notes}

1. The only exceptions are likely to be in cases where an entirely nominal campaign is mounted because the electoral prospects are very poor and party organisation virtually non-existent. The law still requires the appointment of an agent in such cases but the person appointed may not do very much beyond signing the necessary forms and turning up for the counting of votes.

2. The Nuffield study of the 1950 general election contains some interesting information on agents at that time (Nicholas, 1951: 22-41) while Denver and Hands (1997: 325) provide a single table showing the characteristics of agents responding to their 1992 survey.

3. These figures may well underestimate the numbers of constituency parties having the services of a full-time agent since it was common, particularly in the Labour party, for a single agent to have responsibility for more than one constituency, especially in cities. Except where otherwise noted, the figures for full-time agents given in this and later paragraphs are derived from the relevant Nuffield study and, for recent elections, interviews with party organisers.

4. The surveys were conducted in connection with ESRC-supported studies of constituency campaigning. The grant reference numbers are Y304 253004 (1992); R000222027 (1997) and R000239396 (2001).

5. In what follows we use the term 'permanent agents' to refer to those permanently employed on a full-time or part-time basis by the local party. The collective term 'other paid agents' is used to refer to those appointed on national contracts, researchers or 
assistants to MPs or MEPs seconded to act as agents, or special organisers appointed on short-term contracts for the period leading up to and including the election campaign.

6. For each year, the difference between the Conservatives and the other parties in respect of the proportion of males is statistically significant on the basis of chi-squared tests.

7. Using ANOVA to compare means, the differences between volunteers and the other categories are significant in each case. The differences between elections for all Labour and Liberal Democrat agents are also significant - they are becoming significantly older.

8. In planning their election campaigns all parties draw up lists of 'target' constituencies those where they are likely to be involved in a close battle for victory - in which special campaigning efforts are made.

9. Differences in the proportions in the three categories are statistically significant for the Conservatives in 2001, for Labour in 1997 and 2001 and for the Liberal Democrats in all three elections.

10. In 1992 local elections across much of Britain followed one month after the general election. In both 1997 and 2001 there were local elections in some parts of the country on the same day as the general election. 


\section{References}

Bennie, L., Curtice, J. and Rudig, W. (1996) 'Party members' in D. MacIver (ed.) The Liberal Democrats, Hemel Hempstead, Harvester Wheatsheaf.

Blackburn, R. (1995) The Electoral System in Britain, Basingstoke: Macmillan.

Butler, D. and Kavanagh, D. (2002) The British General Election of 2001, Basingstoke, Palgrave.

Butler, D. and Rose, R. (1960) The British General Election of 1959, London: Frank Cass.

Denver, D. and Hands, G. (1997) Modern Constituency Electioneering, London: Frank Cass.

Denver, D. and Hands, G. (2002) 'Post-fordism in the constituencies?' in D. Farrell and R. Schmitt-Beck (eds.) Do Political Campaigns Matter? Campaign effects in elections and referendums, Routledge, London pp. 108-126.

Denver, D., Hands, G. and McAllister I. (2004) 'The Electoral Impact of Constituency Campaigning in Britain, 1992-2001', Political Studies, 52 (2): 289-306.

Denver, D., Hands, G., Fisher, J. and MacAllister, I. (2003) 'Constituency Campaigning in Britain 1992-2001: Centralisation and Modernisation', Party Politics, 9 (5): 541-59.

Fisher, J. \& Webb, P., (2003), 'Party Work as Political Participation: The Vocational Motivations of Labour Party Employees'. The British Journal of Politics \& International Relations, 5 (2): 166-87.

Hanham, H.J., (1978) Elections and Party Management, Sussex, Harvester Press.

Kavanagh, D. (1970), Constituency Electioneering in Britain, London: Longman.

MacAllister, I., Fieldhouse, E., \& Russell, A. (2002) Yellow Fever? The Political Geography of Liberal Voting, Political Geography, 21: 421-47

Nicholas, H. G. (1951) The British General Election of 1950, London: Macmillan.

Pattie C. and Johnston, R. (2003) 'Local battles in a national landslide: constituency campaigning at the 2001 British General Election', Political Geography, 22, 381-414.

Seyd, P. \& Whiteley, P. (2002) New Labour's Grassroots, Basingstoke: Macmillan.

Swaddle, K. (1990) 'Coping with a Mass Electorate: A Study in the Evolution of Constituency Electioneering in Britain with Special Emphasis on the Periods which followed the Reform Acts of 1884 And 1916', unpublished D.Phil thesis, Oxford University.

Whiteley, P. and Seyd, P. (2003) 'How to win a landslide by really trying: the effects of local campaigning on voting in the 1997 British general election', Electoral Studies, 22 (3): 301-24. 
Unsung Heroes

Whiteley, P., Seyd, P. \& Richardson, J. (1994) True Blues, Oxford: Oxford University Press. 